\title{
TEIXEIRA, Faustino - MENEZES, Renata, (orgs): Catolicismo Plural. Dinâmicas contemporâneas. Petrópolis: Vozes, 2009.
}

\author{
Plural Catholicism. Contemporary dynamics.
}

João Batista Libanio*

Esse livro nasce de um seminário organizado pelo ISER Assessoria (abril de 2005) do qual fizeram parte diversos especialistas brasileiros das áreas de ciências sociais, história e teologia. O livro retrata as apresentações dos participantes, resultantes dos escritos preparados e discussões travadas. Coube a F. Teixeira e a R. Menezes a tarefa de preparar a publicação e de brindar-nos com excelente introdução. Esta já abre o apetite do leitor para ir ao encontro do seu interesse específico. A temática se espraia por diversos campos de saber. Predomina o tom analítico com os instrumentais próprios da especialidade de cada autor/a.

A pluralidade de viver o catolicismo salta aos olhos. Numa mesma celebração, sentam-se nos mesmos bancos pessoas cujas visões da fé católica variam enormemente. E se sairmos das igrejas, aí encontraremos outras maneiras de viver o catolicismo. Tal fenômeno tem atraído a atenção de estudiosos. Esse livro vem ao encontro de tal interesse.

Os dados estatísticos estão aí para mostrar a mudança significativa da posição da Igreja católica, antes maioria esmagadora para a faixa dos 73,57 (Censo de 2000). O pluralismo externo à Igreja católica cresce enormemente e também no seu interior. É fácil ser católico (A. F. Pierucci), daí sê-lo de muitos modos: santoral com sua concepção de santidade e de devoção, e oficial (R. Menezes), reafiliado, midiático (F. Teixeira), de comunidade eclesial de base (I. Lesbaupin), tocado por movimentos de reavivamentos, como o caso da Toca de Assis (C. Mariz-P. V. Leite Lopes), sincrético, poroso, milenarista e messiânico (R. Campos). Acontece fácil trânsito entre as confissões (A. Rumstain-R. de Almeida), sem falar de duas ou mais pertenças.

\footnotetext{
* Doutor em Teologia (Gregoria-Roma) e professor da FAJE (Faculdade Jesuíta de Filosofia e Teologia). Email: secteologia@faculdadejesuita.edu.br
}

Horizonte, Belo Horizonte, v. 8, n. 18, p. 228-229, jul./set. 2010 
Esse caleidoscópico florilégio do catolicismo brasileiro, a cujos títulos apenas acenei, se complementa com reflexões teóricas sobre a atual cultura brasileira, vista como delimitação essencial e clara de fronteiras numa unidade identitária em face da alteridade ou como articuladora dialética de temporalidades diversas e de espaços definidos (C. Steil). A conjuntura internacional católica defronta-se com o fenômeno das outras tradições religiosas nos pontificados de João Paulo II e Bento XVI (F. Teixeira). E apontam-se as perspectivas antropológicas do Catolicismo, não restrito à Igreja católica, mas enquanto uma estrutura, princípio regulador que escapa à concepção puramente racional e sim expresso em fórmulas dinâmicas, significativas, cambiantes. Tal princípio se caracteriza por uma sacramentalidade institucional (P. Sanchis). Fecham o livro breves palavras sábias de quem pensou alto sobre o conjunto das pesquisas (O. Velho).

A aparente homogeneidade da Igreja católica, que se define por um credo, leis canônicas, práticas litúrgicas, pastorais organizadas, movimentos de apostolado e espiritualidade, ordens religiosas e outros elementos institucionais, surge da leitura muito mais plural, fragmentada de um lado e porosa de outro. Vale a pena conferir tal leitura. 